\title{
PENGARUH MODUL MODIFIKASI TENTANG PEMBERIAN ASIDAN MP-ASI TERHADAP PENCEGAHAN STUNTING POTENSIAL DI KABUPATEN BIMA
}

\author{
DhanyDahniarti ${ }^{*}$ Nurlaila Fitriani \\ STIKES Yahya Bima ${ }^{l}$ \\ e-mail: dhanydaniarti1@gmail.com*
}

\begin{abstract}
The poor complementary breastfeeding is a risk factor directly related to the stunting. This study was aimed to know the effect of providing information to the baby's mother on the knowledge, attitudes, norms/culture, beliefs, and the actions in giving the complementary breastfeeding in preventing the potential stunting in Bima This study used quasy experiment, ie the pre-test and post-test with control group design. The samples were 40 mothers divided into four groups such as ie classes with modules while the control class researchers with KIA book, a group of researchers only use the modules and control group with KIA book. Questionnaire data collection of interviews and anthropometric measurements. Data were analyzed with the Wilcoxon test. The results showed the effect of information on knowledge, attitudes, norms / culture, significant trust began a second measurement of the classes either the mother or the book module KIA, changes in feeding patterns solids in class + KIA book significantly in the third measurement. In the group of modules, changes in knowledge, norms / culture, and significant confidence in the measurement, while attitudes and solids feeding patterns significantly in the third measurement. At KIA book group, a significant increase in knowledge begin in the second measurement, norms / culture and significant confidence in the third measurement, whereas his own attitude changes are significant in the fourth measurement.
\end{abstract}

Keywords: Modification module, Knowledge,Breast Milk,Complementary Breastfeeding, Stunting.

\begin{abstract}
ABSTRAK
Pemberian ASI dan MP ASI yang kurang baik merupakan faktor risiko yang berhubungan langsung dengan stunting. Penelitian ini bertujuan untuk mengetahui pengaruh modul modifikasi kepada ibu bayi terhadap pengetahuan, tindakan dalam pemberian ASI dan MP ASI dalam mencegah stunting potensial di Kabupaten Bima.Penelitian ini menggunakan quasy experiment yaitu pre-test dan post-test with control group design. Sampel berjumlah 40 ibu yang dibagi menjadi empat kelompok yaitu kelas dengan modul sedangkan kelas kontrol peneliti dengan buku KIA, kelompok peneliti hanya menggunakan modul dan kelompok kontrol dengan buku KIA. Pengumpulan data kuisioner wawancara dan pengukuran antropometri. Data dianalisis dengan uji Wilcoxon. Hasil penelitian menunjukkan pengaruh informasi terhadap pengetahuan, sikap, norma / budaya, signifikan kepercayaan mulai pengukuran kedua kelas baik ibu maupun buku modul KIA, perubahan pola makan makanan padat di kelas + buku KIA signifikan pada pengukuran ketiga. Pada kelompok modul, perubahan pengetahuan, norma / budaya, dan keyakinan signifikan pada pengukuran, sedangkan sikap dan pola makan makanan padat signifikan pada pengukuran ketiga. Pada kelompok buku KIA, peningkatan pengetahuan yang signifikan dimulai pada pengukuran kedua, norma / budaya dan kepercayaan yang signifikan pada pengukuran ketiga, sedangkan perubahan sikap sendiri signifikan pada pengukuran keempat.
\end{abstract}

Kata kunci: Modul modifikasi, ASI, MP ASI, Stunting.

\section{PENDAHULUAN}

Stunting merupakan salah satu indikator gizi kronis yang dapat memberikan gambaran gangguan keadan sosial ekonomi keseluruhan di masa lampau. Stunting diketahui dengan melakukan pengukuran indikator tinggi badan menurut umur $(\mathrm{TB} / \mathrm{U})$ (Bappenas, 2012). Kejadian balita pendek atau biasa disebut dengan stunting merupakan salah satu masalah gizi yang dialami oleh balita di dunia saat ini. Pada tahun 2017 22,2\% atau sekitar 150,8 juta balita di dunia mengalami stunting. Namun angka ini sudah mengalami penurunan jika dibandingkan dengan angka stunting pada tahun 2000 yaitu 32,6\%. (Riskesda, 2018).

Riset Kesehatan Dasar (Riskesdas) 2018 menunjukkan bahwa angka stunting atau balita pendek di Indonesia turun dari 37,2 persen pada Riskesdas 2013 menjadi 30,8 persen. Meskipun telah terjadi penurunan angka kejadian stunting pada Riskesdas 2018, namun di beberapa Provinsi di Indonesia terutama di kawasan timur Indonesia menunjukkan peningkatan angka kejadian stunting. Prevalensi Stunting di Nusa Tenggara barat yaitu 
37,2\% sedangkan di kabupaten Bima sendiri kejadian stunting $36,7 \%$. Intervensi untuk menurunkan anak pendek harus dimulai semasa kehamilan, hingga anak usia usia dua tahun. Status gizi ibu selama hamil dan asupan gizi yang cukup akan membuat janin tumbuh sehat dan anak lahir dengan berat badan lahir dan panjang badan normal (Christian, 2013).

Pemberian makanan pendamping yang optimal pada usia 6-24 bulan memberikan kontribusi bermaksa pada pertumbuhan otak anak. Pada usia 0-6 bulan terjadi pertumbuhan otak hingga mencapai sekitar $75 \%$, masa ini disebut periode emas (golden periode). Pemberian ASI Eksklusif dapat memenuhi seluruh kebutuhan bayi, serta melindungi bayi dari berbagai penyakit seperti diare dan ISPA. Inisiasi menyusu dini (IMD), pemerian ASI Eksklusif dan pemebrian makanan pendamping ASI yang tepat waktu dan berkualitas juga dapat menurunkan angka kematian balita 6\% (Bappenas, 2012). Pemberian makan yang tidak tepat dapat mengakibatkan masih cukup banyak anak yang menderita kurang gizi. Fenomena "gagal tumbuh" atau growth faltering pada anak Indonesia mulai terjadi pada usia 4-6 bulan ketika bayi diberi makanan tambahan dan terus memburuk hingga usia 18-24 bulan. Kekurangan gizi memberi kontribusi 2/3 kematian balita. Dua pertiga kematian tersebut terkait dengan praktik pemberian makan yang tidak tepat pada bayi dan anak usia dini (Suparyanto, 2013).

Salah satu program yang dapat membantu pencegahan terjadinya stunting adlah buku Kesehatan Ibu dan anak (Buku KIA). Ibu perlu diajar tentang isi buku KIA dan cara menggunakan buku KIA. Salah satu solusi yaitu melalui penyelenggaranaan kelas ibu bayi. Kelas ibu bayi dapat membantu ibu untuk meningkatkan pengetahuan sehingga dapat merubah perilaku mereka tentang cara perawatan bayi, upaya menjaga kesehatan bayi dengan menerapkan pola asuh yang baik dan pemberian ASI dan MP-ASI (Kemenkes RI, 2013, IDAI 2005). Kelas ibu bayi di Kabupaten Bima telah dilaksanakan sejak tahun 2009. Walaupun telah dilaksanakan namun prevalensi stunting di kabupaten Bima masih tinggi (sekitar $40 \%$ ), sehingga perlu dikembangkan kelas ibu dengan modul modifikasi. Pemberian informasi ini akan diharapkan akan merubah perilaku ibu dan memerikanASI dan MP-ASI yang benar sehingga dapat mencegah stunting.

\section{METODE}

Penelitian ini merupakan penelitian kuantitatif dengan menggunakan rancangan "Quasy Eksperimen" dengan Pre-test and Post-test with Control Group Desain untuk mengetahui gejala atau pengaruh yang timbul, sebagai akibat dari adanya perlakuan tertentu atau eksperimen. Pada dasarnya rancangan ini adalah rancangan rangkaian waktu, hanya saja menggunakan kelompok pembanding (kontrol). Subjek penelitian disini adalah Semua ibu menyusui yang memiliki bayi 6 bulan yang akan dibagi dalam dua kelompok yaitu kelompok perlakuan (eksperimen) dan kelompok kontrol. Kedua kelompok penelitian ini sama-sama akan mengikti Kelas Ibu Balita. Adapaun yang membedakan kelompok perlakuan akan mendapatkan informasi dari buku KIA dan Modul Modifikasi sedangkan kelompok kontrol hanya mendapat informasi dari Buku KIA.

\section{HASIL}

Analisis Univariat

Tabel 1

Karakteristik Responden

\begin{tabular}{llcc}
\multicolumn{2}{c}{ Karakteristik } & \multicolumn{2}{c}{ Kelompok } \\
\cline { 3 - 4 } & & $\begin{array}{c}\text { Modul } \\
\text { Modifikasi } \\
\text { +Buku KIA }\end{array}$ & $\begin{array}{c}\text { Buku } \\
\text { KIA }\end{array}$ \\
Umur & & 12 & \\
& $20-35$ & 14 & 20 \\
Pendidikan & Rendah & 4 & \\
Pekerjaan & Tinggi & 8 & 13 \\
& IRT & 12 & 7 \\
& PNS & 18 & 3 \\
Paritas & Wiraswasta & 1 & 1 \\
& Petani & 1 & 15 \\
Pendapatan & $<4$ & 15 & 16 \\
keluarga & $>=4$ & 5 & 4 \\
& $>=$ & 4 & 10 \\
& 2.013 .000 & 16 & 10 \\
\hline
\end{tabular}

Berdasarkan tabel 1 diatas,responden kelompok modul didominasi oleh ibu-ibu yang berusia 20-35 tahun (70\%) Paritasnya kurang dari empat (75\%), tingkat pendidikan rendah (60\%),dan bekerja sebagai ibu rumah tangga (90\%). Selain itu, pendapatan keluarga kurang dari standar minimum $(80 \%)$.

Responden kelompok buku pedoman Kesehatan Ibu Anak (KIA) lebih banyak pada kelompok umur 20-35 tahun(100\%), dengan paritas kurang dari empat (80\%), pendidikan tinggi (65\%), pekerjaan sebagai ibu rumah tangga (75\%), dan pendapatan keluarga lebih dari standarminimum $(50 \%)$ 


\section{Analisa Bivariat}

Tabel 2

Pengaruh Modul Modifikasi terhadap pengetahuan dan pemberian ASI MP ASI

\begin{tabular}{|c|c|c|c|}
\hline Pengetahuan & 6 & 7 & 8 \\
\hline $\begin{array}{l}\text { Modul Modifikas } \\
\text { Buku KIA }\end{array}$ & & & \\
\hline Pengetahuan & 4.95 & $6.35 * * *$ & $7.60 * * *$ \\
\hline $\begin{array}{l}\text { Pemberian ASI } \\
\text { dan MP ASI } \\
\text { BUKU KIA }\end{array}$ & 1,5 & $2,5^{*}$ & $3,5^{*}$ \\
\hline Pengetahuan & 4.70 & $6.50 * * *$ & $7.45 * * *$ \\
\hline $\begin{array}{l}\text { Pemberian ASI } \\
\text { dan MP ASI }\end{array}$ & 1 & $2,5^{*}$ & $3 *$ \\
\hline
\end{tabular}

Hasil penelitian menunjukkan terdapat pengaruh modul modifikasi terhadap pemberiaan ASI dan Makanan pendamping ASI, kedua kelompok mengalami perubahan yang signifikan tetapi kelompok intervensi (modul + buku KIA) lebih bermakna dinbandingkan kelompok control (buku KIA).

\section{PEMBAHASAN}

\section{Pemberian ASI}

ASI Eksklusif adalah pemberian ASI saja tanpa tambahan cairan seperti susu formula, jeruk, madu, air teh, air putih dan tanpa tambahan makanan padat seperti pisang, pepaya, bubur susu, biskuit, bubur nasi dan tim (Roesli, 2009). Secara klasik zat gizi dihubungkan dengan kesehatan tubuh, yaitu untuk menyediakan energi, membangun, dan memelihara jaringan tubuh, serta mengatur prosesproses kehidupan dalam tubuh. Zat gizi bagi bayi kurang dari 6 bulan sudah tercukupi hanya dengan ASI saja (Almatsier, 2004). Dalam surat keputusan Menteri Kesehatan Republik Indonesia Nomor 450/MENKES/SK/IV/2004 tentang pemberian ASI secara Eksklusif pada bayi di Indonesia menetapkan Pertama: Keputusan menteri kesehatan tentang pemberian air susu ibu (ASI) secara eksklusif bagi bayi di Indonesia, Kedua: Menetapkan pemberian Air Susu Ibu (ASI) secara eksklusif bagi bayi di Indonesia sejak bayi lahir sampai dengan bayi berumur 6 (enam) bulan dan dianjurkan dilanjutkan sampai anak berusia 2 tahun dengan pemberian makanan tambahan yang sesuai, Ketiga: Semua tenaga kesehatan yang bekerja di sarana pelayanan kesehatan agar menginformasikan kepada semua Ibu yang baru melahirkan untuk memberikan ASI eksklusif (Kemenkes RI, 2004).

Hal ini juga ditekankan dalam Peraturan Pemerintah Republik Indonesia Nomor 33 tahun 2012 tentang pemberian ASI eksklusif pada pasal 6 menyatakan bahwasannya setiap ibu yang melahirkan harus memberikan ASI eksklusif kepada bayi yang dilahirkan (Kemenkes RI, 2012) Pemberian ASI eksklusif merupakan faktor penunjang kecerdasan si bayi, memang tidak mudah karena sang ibu harus memberikannya selama 6 bulan, masa 6 bulan inilah yang disebut ASI eksklusif. Pada masa 6 bulan bayi memang belum diberi makanan selain susu untuk itu ibu harus memberikan perhatian yang ekstra pada bayi. Namun sering kali kesalahan yang terjadi adalah setelah masa ASI eksklusif pada saat bayi sudah bisa Tinjauan pustaka tidak lebih dari 1000 kata dengan mengemukakan state of the art dalam bidang yang diteliti. Bagan dapat dibuat dalam bentuk JPG/PNG yang kemudian disisipkan dalam isian ini. Sumber pustaka/referensi primer yang relevan dan dengan mengutamakan hasil penelitian pada jurnal ilmiah dan/atau paten yang terkini. Disarankan penggunaan sumber pustaka 10 tahun terakhir. mengonsumsi makanan lain selain ASI maka ibu tidak memberikan ASI lagi. Padahal menurut standar kesehatan WHO bayi sebaiknya disapih setelah 2 tahun usianya(Roesli, 2009).

Permasalahan ASI eksklusif juga terjadi pada ibu yang bekerja di kantoran, untuk itu pemerintah mencoba memberikan keleluasaan pada ibu yang pada masa pemberian ASI eksklusif boleh membawa anak ikut serta bekerja atau mengijinkannya memberi jam khusus untuk menyusui bayinya. Pemberian ASI secara mutlak, penting dilakukan, mengingat manfaat yang akan diperoleh si bayi. Menurut WHO hal ini untuk menghindari alergi dan menjamin kesehatan bayi secara optimal. Karena di usia ini, bayi belum memiliki enzim pencernaan sempurna untuk mencerna makanan atau minuman lain. Meski begitu kebutuhan si buah hati akan zat gizi akan terpenuhi jika mengonsumsi ASI. Selain itu ASI jauh lebih sempurna dibandingkan susu formula manapunyang biasanya berbahan susu sapi. Kandungan protein dan laktosa pada susu manusia dan susu sapi itu berbeda. Susu sapi kadar proteinnya lebih tinggi, yakni 3,4\% sedangkan susu manusia hanya $0,9 \%$. Kadar laktosa susu manusia lebih tinggi yakni $7 \%$ sedangkan susu sapi hanya 3,8\% (Roesli, 2009)

\section{Pemberian MP-ASI}

MP-ASI adalah makanan dan minuman yang mengandung gizi yang debrikan pada bayi atau anak berumur 6-24 bulan untuk memenuhi kebutuhan gizinya, tujuan pengenalan MPASI bukan hanya untuk memenuhi kebutuhan nutrisi bayi tetapi juga untuk memperkenalkan pola makan kelurga pada bayi. Makanan pendamping ASI dini adalah makanan atau minuman yabg diberikan pada bayi sebelum berusia 6 bulan. (Roesli, 2009) Salah satu peran pemerintah untuk menjamin kesehatan warnganya adalah dengan mengeluarkan kebijakan yang mengatur mengenai pemberian ASI Eksklusif dan makanan pendamping ASI(MP-ASI), misalnya PERMENKES No.450/Menkes/SK/IV/2004 dan PP No. 33/2012 mengenai pemberian ASI Eksklusif dan 
PP No. 237/1997 mengenai makanan pendamping ASI. MP_ASI bukanlah makanan pengganti ASI melainkan perannya hanya mendampingi pemberian ASI saja, ASI tetaplah dilanjutkan hingga usia 2 tahun (Kemenkes RI, 2019).

\section{Stunting}

Stunting adalah kegagalan untuk mencapai pertumbuhan yang optimal, diukur berdasarkan TB/U (tinggi badan menurut umur). Stunting atau malnutrisi kronik merupakan bentuk lain dari kegagalan pertumbuhan. Stunting adalah gangguan pertumbuhan fisik yang sudah lewat, berupa penurunan kecepatan pertumbuhan dalam perkembangan manusia yang merupakan dampak utama dari gizi kurang. Gizi kurang merupakan hasil dari ketidak seimbangan faktor-faktor pertumbuhan (faktor internal dan eksternal). Gizi kurang dapat terjadi selama beberapa periode pertumbuhan, seperti masa kehamilan, masa perinatal, masa menyusui, bayi dan masa pertumbuhan (masa anak). Hal ini juga bisa disebabkan karena defisiensi dari berbagai zat gizi, misalnya mikronutrien, protein atau energi (Kemenkes RI, 2018).

Pertumbuhan (growth) berkaitan dengan perubahan dalam besar, jumlah, ukuran dan fungsi tingkat sel, organ maupun individu, yang diukur dengan ukuran berat (gram, pound, kilogram), ukuran panjang (cm, meter), umur tulang dan keseimbangan motolik (retensi kalsium, dan nitrogen tubuh). Pertumbuhan adalah peningkatan secara bertahap dari tubuh, organ dan jaringan dari masa konsepsi sampai remaja (Supariasa, et al, 2012). Tinggi badan menurut umur (TB/U) adalah indikator untuk mengetahui seseorang anak stunting atau normal. Tinggi badan merupakan ukuran antropometri yang menggambarkan pertumbuhan skeletal. Dalam keadaan normal, tinggi badan tumbuh seiring pertambahan umur. Pertumbuhan tinggi badan relatif kurang sensitif terhadap masalah kekurangan gizi dalam waktu yang pendek. Indeks TB/U menggambarkan status gizi masa lampau serta erat kaitannya dengan sosial ekonomi. Salah satu metode penilaian status gizi secara langsung yang paling populer dan dapat diterapkan untuk populasi dengan jumlah sampel besar adalah antropometri. Di Indonesia antropometri telah digunakan secara luas sebagai alat untuk menilai status gizi masyarakat dan pertumbuhan perorang pada beberapa dasawarsa belakang ini. Antropometri sebagai indikator status gizi dapat dilakukan dengan mengukur beberapa parameter, sedangkan parameter adalah ukuran tunggal dari ukuran tubuh manusia. Tinggi badan merupakan parameter yang penting bagi keadaan yang telah lalu dan keadaan sekarang. Pengukurang tinggi badan atau panjang badan pada anak dapat dilakukan dengan alat pengukur tinggi/panjang badan dengan presisi $0.1 \mathrm{~cm}$. (Supariasa et al, 2012).

Penggunaan indeks TB/U memiliki beberapa kelebihan antara lain 1) merupakan indikator yang baik untuk mengetahui kurang gizi pada masa lampau. 2) Alat mudah dibawa-bawa, murah. 3) Pengukuran objektif. Sedangkan kelemahannya antara lain : 1) dalam penilaian intervensi harus disertai dengan indeks lain (seperti BB/U), karena perubahan tinggi badan tidak banyak terjadi dalam waktu singkat, 2) ketepatan umur sulit didapat. Indikator $\mathrm{TB} / \mathrm{U}$ memberikan indikasi masalah gizi yang sifatnya kronik sebagai akibat dari keadaan berlangsung lama, misalnya kemiskinan, perilaku hidup sehat dan pola asuh/pemberian makanan yang kurang baik dari sejak anak dilahirkan yang mengakibatkan anak menjadi pendek (Riskesdas, 2018).

\section{KESIMPULAN}

Pengaruh informasi ibu bayi dalam pemberian ASI dan MPASI tambahan terhadap pengetahuan,sikap, norma / budaya, kepercayaan, dan tindakan ibu dalam pemberian ASI pendamping pada semua kelompok, Baik kelas modul maupun kelas buku KIA mengalami peningkatan pada pengukuran kedua

\section{DAFTAR PUSTAKA}

1. Bappenas, 2011.Rencana Aksi Nasional dan Gizi 2011-2015. Jakarta.

2. Fatmawati., et.al. 2016. The Effect of the Baby's Mother Information in Providing Complementary Breastfeeding on the Prevention of Potential Stunting in Kendari. Hasanuddin University

3. Dewey K.G. \& Mayers D.R. 2011 Early Child Growth: How Do Nutrition and Infection Interact? Maternal \&Child Nutrition 7 (Suppl. 3), 129-142.

4. Victora C.G., et.al. 2010. Worldwide Timing of Growth Faltering: Revisiting Implications for Interventions. Pediatrics 125, e473-e480.

5. Bhutta Z.A.,et al. 2013 Evidence-based Interventions for Improvement of Maternal and Child Nutrition: What Can Be Done and at What Cost? Lancet 382, 452-477.

6. WHO-World Bank Joint. 2010. Child Malnutrition Estimates. UNICEF, New York; WHO, Geneva; The World Bank, Washington, DC.

7. Kemenkes RI. 2013 Laporan Nasional Riset Kesehatan Dasar (Riskesdas) 2013. Badan Penelitian Pengembangan Kesehatan Departemen Kesehatan Republik Indonesia

8. Suprapti, 2013. Pengaruh Pemberian Asi Eksklusif Dan Sikap Ibu Terhadap Pertumbuhan 
Bayi Di Puskesmas Menganti Gresik. Magister Kedokteran Keluarga, Post-Graduated Program, University of Sebelas Maret, Surakarta.

9. Mukhlisa N, 2013. Hubungan Antara Pemberian Asi Eksklusif Dengan Pertumbuhan Bayi Usia 06 Bulan Di Puskesmas Kassi-Kassi Kota Makassar, Medical Faculty of Indonesia Moslem University. Makassar.

10. Jafar N. 2012. Peranan Anemia pada Ibu Hamil. Nutritional Science. Faculty of Public Health. Hasanuddin University. Makassar.

11. Wahyuningsih S. 2014. Pengaruh Model Pendidikan Pembuatan Makanan Pendamping ASI Terhadap Pengetahuan Ibu Dan Status Gizi Anak Bawah Lima Tahun. Thesis. University of Sebelas Maret, Surakarta.

12. Jompa, Hariani. 2003. Perilaku Menyusui Bayi Pada Etnik Bugis (Studi Etnologi Pada Masyarakat Bugis di Pekkae). Thesis. PostGraduated Program. Hasanuddin University. Makassar.

13. Depkes, RI. 2009. Pelatihan Kelas Ibu (Kelas Ibu Hamil dan Kelas Ibu Bayi ) untuk Petugas Kesehatan, Buku Pegangan Pelatih. Jakarta

14. Salimar, 2009. Role of Guidance in Using the Tool Change Leaflet Knowledge and Attitudes about Nutrition Toddler Mom. The Journal of Food and Nutrition Research, 32 (2): 122-130. Bogor: Center for Research and Development in Food and Nutrition.

15. Nikmawati. Et.al. 2009. Intervensi Pendidikan Gizi bagi Ibu Balita dan Kader Posyandu untuk
Meningkatkan PSK (Pengetahuan Sikap Dan Keterampilan) serta Status Gizi Balita. Jurnal Tata Boga. Vol. V No. 15 August 2009

16. Rahmawati. 2007. Pengaruh Penyuluhan dengan Media Audiovisualterhadap Peningkatan Pengetahuan, Sikap dan Perilaku Ibu Balita Gizi Kurang dan Buruk di Kabupaten Kotawaringin Barat Propinsi Kalimantan Tengah

17. Notoatmodjo, S. 2010. Promosi Kesehatan dan Ilmu Perilaku. Jakarta : Rineka Cipta

18. Siregar MA. 2004. Pengaruh Pengetahuan Ibu Terhadap Kurang Kalori Protein Pada Balita. USU digital library.

19. Soetjiningsih. 2012. Tumbuh Kembang Anak. Jakarta: EGC.

20. Fisher, E, Helendra dan Amri, E. 2012. Hubungan Tingkat Pengetahuan Ibu Tentang Gizi dengan Status Gizi Balita di Desa Sioban Kabupaten Kepulauan Mentawai. Padang: Biology Education. STKIP PGRI Sumatera Barat

21. Setijowati N, Wirawan NN, Apriyanto D. 2010. Perbedaan Pola Asuh Makan pada Berbagai Tingkatan Posyandu terhadap Tingkat Konsumsi Energi dan Protein Balita. Studi Kasus di Kecamatan Moyo Hulu Kabupaten Sumbawa NTB

22. Ardianto E. Komala L. Karlinah S. 2014. Komunikasi Massa Suatu Pengantar. Simbiosa Rekatma Media Bandung. 